\title{
Isolation of isoform-specific binding proteins (Affimers) by phage display using negative selection**
}

Anna Ah-San Tang ${ }^{1,2}$, Christian Tiede ${ }^{1,2}$, David J. Hughes ${ }^{4}$, Michael McPherson ${ }^{1,2,3}$, Darren C.

Tomlinson $^{1,2,3 *}$

${ }^{1}$ School of Molecular \& Cellular Biology, ${ }^{2}$ BioScreening Technology Group and ${ }^{3}$ Astbury Centre for

Structural Molecular Biology, Faculty of Biological Sciences, University of Leeds, Leeds U.K., LS2 9JT.

${ }^{4}$ Biomedical Sciences Research Complex, University of St. Andrews, St. Andrews U.K. KY16 9ST.

*Corresponding author: Dr Darren C. Tomlinson (d.c.tomlinson@leeds.ac.uk)

\footnotetext{
${ }^{* *}$ This manuscript has been accepted for publication in Science Signaling. This version has not undergone final editing. Please refer to the complete version of record at http://www.sciencesignaling.org/. The manuscript may not be reproduced or used in any manner that does not fall within the fair use provisions of the Copyright Act without the prior, written permission of AAAS.
} 


\begin{abstract}
Some thirty years after its discovery, phage display remains one of the most widely used in vitro selection methods. Initially developed to revolutionise the generation of therapeutic antibodies, phage display is now the first choice for screening artificial binding proteins. Artificial binding proteins can be used as reagents to study protein-protein interactions, to target posttranslational modifications, to distinguish between homologous proteins, as research and affinity reagents, for diagnostics, and as therapeutics. However, the ability to identify isoform-specific reagents remains highly challenging. Here we describe an adapted phage display protocol using an artificial binding protein (Affimer) for the selection of isoform-selective binding proteins.
\end{abstract}

\title{
Introduction
}

There is a critical need for highly selective antibodies in biological research, diagnostics, and therapy. However, there is a widespread lack of reproducibility and selectivity of antibodies and a growing drive to use methods that directly yield recombinant binding reagents that can be sequenced and easily produced in a reproducible manner $(1,2)$. These include artificial binding proteins such as DARPins (3), monobodies (4), and Affimers (formerly referred to as Adhirons, (5-7), which offer the advantages of recombinant bacterial production as well as the ability to be expressed in mammalian cells to study protein function. The Adhiron scaffold, depicted in Fig. 1, was derived from a consensus sequence of phytocystatins and was designed to constrain two separate variable peptide sequences for molecular recognition (5). It is related in structure to a previously reported scaffold engineered from human Stefin 
A (8). Non-antibody binding proteins derived from these two scaffolds are now referred to collectively as Affimers, and the utility of Affimer technology as affinity reagents has been demonstrated (7).

Despite the growing number of methods for isolating protein-binding reagents, such as ribosomal display (9), cis-display (10) and mRNA display (11), phage display remains the most widely used approach. Phage display was developed over thirty years ago (12) and has since been adapted for presenting large libraries of antibody fragments, peptides, and artificial binding proteins. Phage display is performed by mixing highly complex libraries of phage that display the binding moiety with purified target molecules normally presented as immobilised antigens on solid surfaces. This immobilisation is commonly accomplished by direct adsorption to a solid surface by or chemical modifcation of the antigen using biotin linkers to immobilize them on streptavidin-coated surfaces. After three to five panning rounds, monoclonal phage displaying the selected binding reagents are tested to confirm their ability to bind to the target antigen. These clones are sequenced, and the coding regions are sub-cloned into expression vectors. This process typically takes two to three weeks and can yield reagents with binding affinities suitable for many applications.

Here we describe a phage display strategy performed with an Affimer phage display library that uses relatively low amounts of target and non-target homologous antigens, making it suitable for proteins that are expensive or difficult to express (5). This method (Fig. 2) allows selection of highly specific Affimer clones that are able to discriminate between protein isoforms with very similar threedimensional structures. This method includes a process of negative selection wherein small amounts of the homologous proteins, for which you wish to deselect against, are premixed with the phage library from the second round of panning onward, both as immobilised proteins and as proteins in solution. In theory, this process allows capture or blocking of the cross-reactive Affimer-displaying phage, thereby allowing the highly selective Affimers to be enriched and isolated throughout the subsequent panning 
rounds. This protocol could potentially be used for any phage display library when screening to achieve similarly high selectivity and would be particularly useful when developing reagents to to study signalling cascades by blocking protein-protein interactions, such as those mediated by Src homology domains, for which current small molecule inhibitors lack specificity.

\section{Materials}

\section{Biotinylation of the Target Protein}

Target protein dissolved in an amine-free buffer such as phosphate-buffered saline between 0.5$20 \mathrm{mg} / \mathrm{ml}$

EZ-Link ${ }^{\mathrm{TM}}$ NHS-Biotin (Thermo Scientific, Cat. No. 20217)

Dimethyl sulfoxide (DMSO)

Phosphate-buffered saline (PBS) (137 mM NaCl; $2.7 \mathrm{mM} \mathrm{KCl} ; 12 \mathrm{mM} \mathrm{Na}_{2} \mathrm{HPO}_{4} ; 1.2 \mathrm{mM} \mathrm{KH}_{2} \mathrm{PO}_{4}$; $\mathrm{pH}$ 7.4) or other amine-free buffer at $\mathrm{pH} 7.0-8.0$

Zeba Spin Desalting Columns, 7K MWCO, 0.5 ml (Thermo Scientific, Cat. No. 89882)

$80 \%$ Glycerol stock (in sterile $\mathrm{dH}_{2} \mathrm{O}$ )

\section{ELISA to Check Biotinylation}

Nunc-Immuno ${ }^{\mathrm{TM}}$ MaxiSorp $^{\mathrm{TM}}$ strips (Thermo Scientific, Cat. No. 469949)

Phosphate-buffered saline (PBS)

PBST [PBS with 0.1\% (v/v) Tween-20]

10x Casein Blocking Buffer (Sigma, Cat. No. B6429)

2x Blocking Buffer (10x Casein Blocking Buffer diluted in PBST)

Pierce $^{\mathrm{TM}}$ High Sensitivity Streptavidin-HRP (Thermo Scientific, Cat. No. 21130) 
SeramunBlau ${ }^{\circledR}$ fast TMB/substrate solution (TMB) (Seramun, Cat. No. S-001-TMB)

\section{Affimer Selection by Phage Display}

Biotinylated target protein at $4.2 \mu \mathrm{M}$

Non-biotinylated protein for deselection of isoform-specific binders (10-100 $\mu \mathrm{M})$

E. coli ER2738 cells (Lucigen)

2 TY media [1.6\% (w/v) tryptone; $1 \%(\mathrm{w} / \mathrm{v})$ yeast extract; $0.5 \%(\mathrm{w} / \mathrm{v}) \mathrm{NaCl}]$

Tetracycline hydrochloride (1000x stock: $12 \mathrm{mg} / \mathrm{ml}$ in 70\% ethanol)

Streptavidin-Coated (HBC) 8-well strips (Thermo Scientific, Cat. No. 15501)

$0.2 \mathrm{M}$ glycine, $\mathrm{pH} 2.2$

1M Tris- $\mathrm{HCl}, \mathrm{pH} 9.1$

Triethylamine (Sigma-Aldrich, \#T0886)

1M Tris- $\mathrm{HCl}, \mathrm{pH} 7$

Carbenicillin (500x stock: $50 \mathrm{mg} / \mathrm{ml}$ in $\mathrm{ddH}_{2} \mathrm{O}$ )

LB agar plates with $100 \mu \mathrm{g} / \mathrm{ml}$ carbenicillin

M13K07 helper phage (titre ca. $10^{14} / \mathrm{ml}$ ) (New England Biolabs)

Kanamycin (500x stock: $25 \mathrm{mg} / \mathrm{ml}$ in $\mathrm{ddH}_{2} \mathrm{O}$ )

PEG-NaCl precipitation solution [20\% (w/v) PEG 8000; $2.5 \mathrm{M} \mathrm{NaCl}]$

Tris-EDTA buffer (TE buffer) (10 mM Tris; 1 mM EDTA; pH 8.0)

$80 \%$ glycerol stock (in sterile $\mathrm{dH}_{2} \mathrm{O}$ )

Eppendorf ${ }^{\circledR}$ LoBind microcentrifuge tubes (Eppendorf, Cat. No. 0030 108.116)

Dynabeads ${ }^{\mathrm{TM}}$ MyOne $^{\mathrm{TM}}$ Streptavidin T1, $10 \mathrm{mg} / \mathrm{ml}$ (Thermo Scientific, Cat. No. 65601 or 65602 )

Deep well 96 plate (Thermo Scientific, Cat. No. 95040450)

KingFisher (200 $\mu$ l) 96 plates (Thermo Scientific, Cat. No. 97002540) 
NeutrAvidin-Coated (HBC) 8-well strips (Thermo Scientific, Cat. No. 15508)

Halt Protease Inhibitor Cocktail (100X) (Thermo Scientific, Cat. No. 87786)

\section{Equipment}

Standard molecular biology equipment, including micropipettes and tips, microcentrifuge tubes, etc.

Microcentrifuge

Microplate strip washer (for example, TECAN HydroFlex ${ }^{\mathrm{TM}}$ )

Incubator set at $37^{\circ} \mathrm{C}$

Vibrating platform shaker (for example, Heidolph VIBRAMAX 100)

Microplate reader for measuring absorbance (for example, Multiskan Ascent)

Shaking incubator set at $37^{\circ} \mathrm{C}$ (for $50 \mathrm{ml}$ conical centrifuge tubes)

Tube rotator (for example, Stuart SB2 fixed speed rotator)

KingFisher $^{\mathrm{TM}}$ Flex magnetic particle processor (ThermoFisher Scientific Cat. No. 5400630)

\section{Recipes}

\section{Recipe 1: Phosphate-buffered saline (PBS) and PBST}

Prepare $10 \mathrm{x}$ stock by dissolving $80 \mathrm{~g}$ of $\mathrm{NaCl}(\mathrm{MW}=58.44), 2.0 \mathrm{~g}$ of $\mathrm{KCl}(\mathrm{MW}=74.55), 17.0 \mathrm{~g}$ of $\mathrm{Na}_{2} \mathrm{HPO}_{4}$ ( $\mathrm{MW}=141.96)$, and $1.63 \mathrm{~g}$ of $\mathrm{KH}_{2} \mathrm{PO}_{4}(\mathrm{MW}=136.09)$ in $800 \mathrm{ml}$ of $\mathrm{dH}_{2} \mathrm{O}$. Adjust the $\mathrm{pH}$ to 7.4 with $\mathrm{HCl}$, and then add $\mathrm{dH}_{2} \mathrm{O}$ to $1 \mathrm{~L}$. Autoclave to sterilise. Store at room temperature.

For a $1 \mathrm{x}$ stock of PBS, dilute the $10 \mathrm{x}$ stock with $\mathrm{dH}_{2} \mathrm{O}$ and adjust to $\mathrm{pH} 7.4$ with $\mathrm{HCl}$.

For PBST, dilute the $10 \mathrm{x}$ stock with $\mathrm{dH}_{2} \mathrm{O}$ plus $0.1 \%(\mathrm{v} / \mathrm{v})$ Tween-20 and adjust to $\mathrm{pH} 7.4$ with $\mathrm{HCl}$. 


\section{Recipe 2: 2x Blocking Buffer}

Dilute 10 x Blocking Buffer (Sigma, Cat. No. B6429) 5-fold in PBS.

Recipe 3: 2TY mediaDissolve $16 \mathrm{~g}$ Bacto Tryptone, $10 \mathrm{~g}$ Bacto Yeast Extract, and $5 \mathrm{~g} \mathrm{NaCl}(\mathrm{MW}=58.44)$ in $900 \mathrm{ml}$ ofd $\mathrm{H}_{2} \mathrm{O}$. Adjust the $\mathrm{pH}$ to 7.0 with $\mathrm{NaOH}$, and then add $\mathrm{dH}_{2} \mathrm{O}$ to $1 \mathrm{~L}$. Autoclave to sterilise. Store at room temperature.

\section{Recipe 4: Tetracycline hydrochloride (1000x stock)}

Dissolve $12 \mathrm{mg} / \mathrm{ml}$ in $70 \%$ ethanol and store at $-20^{\circ} \mathrm{C}$ in the dark. Working concentration is $12 \mu \mathrm{g} / \mathrm{ml}$.

\section{Recipe 5: 0.2 M Glycine, pH 2.2}

Dissolve $1.5 \mathrm{~g}$ of glycine $(\mathrm{MW}=75.07)$ in $80 \mathrm{ml}$ of $\mathrm{dH}_{2} \mathrm{O}$. Adjust the $\mathrm{pH}$ to 2.2 with $\mathrm{HCl}$, and then add $\mathrm{H}_{2} \mathrm{O}$ to $100 \mathrm{ml}$. Autoclave to sterilise. Store at room temperature.

\section{Recipe 6: Triethylamine}

Mix $14 \mu \mathrm{l}$ of triethylamine (Sigma-Aldrich, Cat. No. T0886) with $986 \mu \mathrm{l} \mathrm{PBS} \mathrm{immediately} \mathrm{before} \mathrm{use.}$

\section{Recipe 7: 1 M Tris-HCl Stocks}

Dissolve $121.14 \mathrm{~g}$ of Tris base $(\mathrm{MW}=121.14)$ in $800 \mathrm{ml}$ of $\mathrm{dH}_{2} \mathrm{O}$. Adjust $\mathrm{pH}$ to the desired value with concentrated $\mathrm{HCl}$ at room temperature. The $\mathrm{pH}$ of Tris buffers varies with temperature and concentration. Adjust the volume of the solution to $1 \mathrm{~L}$ with $\mathrm{dH}_{2} \mathrm{O}$. Autoclave to sterilise. Store at room temperature.

\section{Recipe 8: Carbenicillin (500x stock)}


Dissolve $50 \mathrm{mg} / \mathrm{ml}$ in $\mathrm{ddH}_{2} \mathrm{O}$. Filter sterilise and store at $-20^{\circ} \mathrm{C}$. Working concentration is $100 \mu \mathrm{g} / \mathrm{ml}$.

\section{Recipe 9: LB agar plates with $100 \mu \mathrm{g} / \mathrm{ml}$ carbenicillin}

Add $32.0 \mathrm{~g}$ of LB agar (Lennox L agar) (ThermoFisher Scientific \#22700041) per $\mathrm{L}$ of $d \mathrm{~d}_{2} \mathrm{O}$. Autoclave to sterilise. Cool to $\sim 50-55^{\circ} \mathrm{C}$. Add carbenicillin to a final concentration of $100 \mu \mathrm{g} / \mathrm{ml}$. Pour into petri dishes and allow to solidify. Store at $4^{\circ} \mathrm{C}$ for up to 2 months.

Alternatively, the formulation for $1 \mathrm{~L}$ of Lennox L agar is as follows: $10 \mathrm{~g}$ SELECT Peptone 140, $5 \mathrm{~g}$ SELECT Yeast Extract, $5 \mathrm{~g}$ Sodium Chloride, $12 \mathrm{~g}$ SELECT Agar. Swirl to mix and autoclave to sterilise.

\section{Recipe 10: Kanamycin (500x stock)}

Dissolve $25 \mathrm{mg} / \mathrm{ml}$ kanamycin in $\mathrm{ddH} 2 \mathrm{O}$. Filter sterilise and store at $-20^{\circ} \mathrm{C}$. Working concentration is 50 $\mu \mathrm{g} / \mathrm{ml}$.

\section{Recipe 11: PEG-NaCl precipitation solution}

Dissolve $200 \mathrm{~g}$ PEG 8000 and $146.1 \mathrm{~g} \mathrm{NaCl}(\mathrm{MW}=58.44)$ in $\mathrm{dH}_{2} \mathrm{O}$ to a total volume of $1 \mathrm{~L}$. Autoclave to sterilise. Store at room temperature.

\section{Recipe 12: Tris-EDTA buffer (TE buffer)}

Prepare stocks of $1 \mathrm{M}$ Tris- $\mathrm{HCl}, \mathrm{pH} 8.0$ (Recipe 5), and 0.5 M EDTA, pH 8.0. To prepare 0.5 M EDTA, pH 8.0, add $93.06 \mathrm{~g}$ of EDTA disodium salt ( $\mathrm{MW}=372.24)$ to $400 \mathrm{ml}$ of $\mathrm{dH}_{2} \mathrm{O}$. Adjust the $\mathrm{pH}$ to 8.0 with $\mathrm{NaOH}$; the disodium salt of EDTA will not dissolve until the $\mathrm{pH}$ of the solution is adjusted to $\mathrm{pH}$ 8.0. Once dissolved, adjust volume to $500 \mathrm{ml}$ with $\mathrm{dH}_{2} \mathrm{O}$. Autoclave to sterilise. Store at room temperature. For $1 \mathrm{~L}$ of $1 \mathrm{x}$ TE Buffer, mix $10 \mathrm{ml}$ of $1 \mathrm{M}$ Tris-HCl, $\mathrm{pH} 8.0$ and $2 \mathrm{ml}$ of $0.5 \mathrm{M}$ EDTA, pH 8.0 with $988 \mathrm{ml}$ of $\mathrm{ddH}_{2} \mathrm{O}$. Store at room temperature. 


\section{Instructions}

\section{Biotinylation of the Target Protein}

The selection procedure is performed against a target protein that is biotinylated and captured on streptavidin- or NeutrAvidin-coated surfaces. Biotinylation reagents that utilise various conjugation chemistries are commercially available. We used the EZ-Link ${ }^{\mathrm{TM}}$ NHS-Biotin reagent, which reacts with primary amines such as the amino termini of polypeptides or the side chain amine of lysine residues.

Note: When screening against biologically active proteins, ensure that the biotinylation does not affect the protein's activity. See the Troubleshooting section for alternative methods of biotinylation.

1. Equilibrate the vial of EZ-Link ${ }^{\mathrm{TM}}$ NHS-Biotin to room temperature before opening.

2. Prepare the target protein in an amine-free buffer at $1 \mathrm{mg} / \mathrm{ml}$.

3. Immediately before use, prepare a $10 \mathrm{mM}$ solution of NHS-Biotin in DMSO by dissolving $2.0 \mathrm{mg}$ of NHS-Biotin in $590 \mu$ l of DMSO.

4. Add a 10-fold molar excess of NHS-Biotin solution to the target protein. For example, add $0.8 \mu \mathrm{l}$ of $10 \mathrm{mM}$ NHS-Biotin to $10 \mu \mathrm{l}$ of a $1 \mathrm{mg} / \mathrm{ml} 12 \mathrm{kDa}$ protein in a total volume of $100 \mu \mathrm{l}$ PBS.

5. Incubate at room temperature for $30 \mathrm{~min}$.

6. Desalt to remove any remaining biotin using Zeba Spin Desalting Columns, 7K MWCO according to the manufacturer's instructions.

7. Mix with an equal volume of $80 \%$ glycerol and store at $-20^{\circ} \mathrm{C}$.

\section{ELISA to check biotinylation}


1. Aliquot $50 \mu \mathrm{l}$ per well of PBS to Nunc-Immuno ${ }^{\mathrm{TM}}$ MaxiSorp $^{\mathrm{TM}}$ strips, and add $1 \mu$ l of biotinylated protein to each well. Incubate overnight at $4^{\circ} \mathrm{C}$.

2. Wash $3 x$ with $300 \mu \mathrm{l}$ PBST per well with a microplate strip washer (e.g. TECAN HydroFlex ${ }^{\mathrm{TM}}$ ).

3. Add $200 \mu \mathrm{l} 2 \times$ Blocking Buffer per well and incubate at $37^{\circ} \mathrm{C}$ for $2-3$ hours.

4. Wash $3 x$ with $300 \mu l$ PBST per well on a microplate strip washer.

5. Dilute High Sensitivity Streptavidin-HRP 1:1000 in 2x Blocking Buffer and add $50 \mu \mathrm{l}$ per well.

6. Incubate for 1 hour at room temperature on a vibrating platform shaker, such as a Heidolph VIBRAMAX 100 set to $300 \mathrm{rpm}$.

7. Wash $6 x$ with $300 \mu \mathrm{l}$ PBST per well on a microplate strip washer.

8. Aliquot $50 \mu \mathrm{TTMB}$ per well and allow to develop. Note the amount of time the plate is allowed to develop; usually, 2-3 minutes is sufficient.

9. Measure absorbance at $620 \mathrm{~nm}$ on a microplate reader.

\section{Affimer Selection by Phage Display - First Panning Round}

\section{DAY 1}

1. Pick a colony of ER2738 E. coli cells into $5 \mathrm{ml} 2 \mathrm{TY}$ media plus $12 \mu \mathrm{g} / \mathrm{ml}$ tetracycline and incubate overnight in an orbital incubator at $37^{\circ} \mathrm{C}, 230 \mathrm{rpm}$.

2. Aliquot $300 \mu \mathrm{l} 2 \times$ Blocking Buffer per well into Streptavidin-coated (HBC) 8-well strips and incubate overnight at $37^{\circ} \mathrm{C}$. Set up 4 wells in total for each target ( 3 wells for pre-panning the phage and 1 well for binding the target and panning with phage).

\section{DAY 2}

3. Wash $3 x$ with $300 \mu \mathrm{l}$ PBST per well on a microplate strip washer.

4. Aliquot $100 \mu \mathrm{l} 2 \times$ Blocking Buffer per well into all wells. 
5. Pre-pan the phage: To the first pre-pan well add $5 \mu$ l of phage library (approximately $10^{12} \mathrm{cfu}$ ). Mix and incubate on a vibrating platform shaker for $40 \mathrm{~min}$. Remove buffer from the $2^{\text {nd }}$ pre-pan well and transfer the buffer containing the phage from the first pre-pan well to the 2 nd pre-pan well. Incubate for $40 \mathrm{~min}$, and then repeat for the $3^{\text {rd }}$ pre-pan well.

6. Whilst pre-panning the phage: Add $20 \mu \mathrm{l}$ (up to $1 \mu \mathrm{g}$ ) of the biotinylated target to the wells to be used for panning. Incubate for 1-2 hours at room temperature on the vibrating platform shaker.

7. Wash the wells containing the target $3 x$ with $300 \mu \mathrm{l}$ PBST per well.

8. Transfer the phage from the pre-pan wells to the wells containing the target and incubate for 2 hours at room temperature on the vibrating platform shaker).

9. In the meantime, set up a fresh culture of ER2738 cells ( $8 \mathrm{ml}$ per target) by diluting the overnight culture to an OD600 of $\sim 0.2$ and incubating for approximately 1 hour at $37^{\circ} \mathrm{C}, 230 \mathrm{rpm}$ until OD600 reaches $\sim 0.6$.

10. Wash the panning well $27 x$ in $300 \mu$ PBST per well on the microplate strip washer.

11. Elute the phage by adding $100 \mu \mathrm{l}$ of $0.2 \mathrm{M}$ glycine, $\mathrm{pH} 2.2$, and incubating for $10 \mathrm{~min}$ at room temperature.

12. Neutralise by adding $15 \mu \mathrm{l}$ of $1 \mathrm{M}$ Tris- $\mathrm{HCl}, \mathrm{pH}$ 9.1. Mix and add immediately to an $8 \mathrm{ml}$ aliquot of the ER2738 cells in a $50 \mathrm{ml}$ falcon tube.

13. Dilute $14 \mu \mathrm{l}$ of Triethylamine with $986 \mu \mathrm{l}$ of PBS.

14. Elute any remaining phage by adding $100 \mu$ of the diluted Triethylamine and incubating for 6 min at room temperature.

15. Neutralise by adding $50 \mu \mathrm{l}$ of $1 \mathrm{M}$ Tris-HCl, $\mathrm{pH}$ 7. Mix and add immediately to the ER2738 cells.

16. Incubate the cells for 1 hour at $37^{\circ} \mathrm{C}$ (no shaking or shake at low speed, $90 \mathrm{rpm}$ maximum). Mix at least once during the incubation period. 
17. Plate $1 \mu \mathrm{l}$ of the phage-infected ER2738 cells onto LB-carb plates (LB agar plates containing 100 $\mu \mathrm{g} / \mathrm{ml}$ carbenicillin) - incubate overnight at $37^{\circ} \mathrm{C}$.

18. Centrifuge the remaining cells at $3,000 \times \mathrm{g}$ for $5 \mathrm{~min}$ and resuspend in a smaller volume and plate onto $\mathrm{LB}$ carb plates - incubate overnight at $37^{\circ} \mathrm{C}$.

\section{DAY 3}

19. Count the colonies on the plates containing $1 \mu$ l of cells to estimate the phage titre - multiply by 8,000 to determine the total number per $8 \mathrm{ml}$ of cells (usually between $0.1-2 \times 10^{6}$ ).

20. Scrape the cells from the remaining plates. To do this, add $5 \mathrm{ml}$ of $2 \mathrm{TY}$ carb (2TY media containing $100 \mathrm{\mu g} / \mathrm{ml}$ carbenicillin) to the plate, scrape using a disposable plastic spreader, transfer to a $50 \mathrm{ml}$ falcon tube and mix. Add an additional $2 \mathrm{ml}$ of $2 \mathrm{TY}$ carb to scrape off any remaining cells.

21. Measure the absorbance at $600 \mathrm{~nm}$ of a 1:10 dilution to determine the dilution required for an $8 \mathrm{ml}$ culture at an OD600 of 0.2 .

22. Dilute the cells in $2 \mathrm{TY}$ carb in $50 \mathrm{ml}$ falcon tubes to achieve an OD600 of 0.2 .

23. Incubate at $37^{\circ} \mathrm{C}, 230 \mathrm{rpm}$, approximately 1 hour until an OD600 of 0.6 .

24. Add $3.2 \mu \mathrm{l}$ of $\mathrm{M} 13 \mathrm{~K} 07$ helper phage (titre ca. $10^{13} / \mathrm{ml}, \mathrm{MOI} \sim 30$ ) and incubate at $37^{\circ} \mathrm{C}, 90 \mathrm{rpm}$, for 30 $\min$.

25. Add $16 \mu$ l of kanamycin $(25 \mathrm{mg} / \mathrm{ml})$ and incubate overnight in an orbital incubator at $25^{\circ} \mathrm{C}, 170 \mathrm{rpm}$.

\section{DAY 4}

26. Centrifuge the phage-infected cultures at 3,500 x g for $10 \mathrm{~min}$.

27. Transfer the phage-containing supernatant to fresh tubes.

28. Remove the required volume of phage-containing supernatant for the second panning round (see below).

29. Add $2 \mathrm{ml}$ of PEG-NaCl precipitation solution (20\% (w/v) PEG 8000, $2.5 \mathrm{M} \mathrm{NaCl}$ ) to the remaining supernatant. Incubate for at least 1 hour or overnight at $4^{\circ} \mathrm{C}$. 
30. Centrifuge at $4,800 \times \mathrm{g}$ for $30 \mathrm{~min}$ to pellet the phage.

31. Pour off the supernatant (blotting the tube on tissue paper to remove all of the supernatant) and resuspend the pellet in $320 \mu \mathrm{l}$ of TE.

32. Transfer to microcentrifuge tubes and centrifuge at $16,000 \times \mathrm{g}$ for $10 \mathrm{~min}$. The supernatant contains the phage. Phage can be stored for several weeks at $4^{\circ} \mathrm{C}$. For long-term storage, add an equal volume of $80 \%$ glycerol, mix thoroughly, and store at $-80^{\circ} \mathrm{C}$.

\section{Affimer Selection by Phage Display - Second Panning Round}

\section{DAY 1}

1. Resuspend the Dynabeads ${ }^{\mathrm{TM}} \mathrm{MyOne}^{\mathrm{TM}}$ Streptavidin T1 magnetic beads in the vial (vortex) and transfer $20 \mu \mathrm{l}$ per target into Eppendorf ${ }^{\circledast}$ LoBind microcentrifuge tubes.

2. Wash the Streptavidin beads by resuspending in $500 \mu \mathrm{l}$ PBST. Place the tube on a magnetic separation rack and discard the supernatant.

3. Resuspend the Streptavidin beads in $300 \mu \mathrm{l}$ of $2 x$ Blocking Buffer and incubate overnight at room temperature on a tube rotator.

\section{DAY 2}

4. Pre-block plates for the KingFisher ${ }^{\mathrm{TM}}$ Flex magnetic particle processor for a minimum of 2 hours at $37^{\circ} \mathrm{C}:$

a. Pre-block one well per target in a deep well 96 plate with $1 \mathrm{ml}$ per well of 2x Blocking Buffer. These wells will be used for panning.

b. Pre-block one well per target in a KingFisher $(200 \mu l) 96$ plates with $300 \mu l$ per well of $2 x$ Blocking Buffer. These wells will be used to recover the Streptavidin beads containing the bound target and selected phage. 
5. Prepare one well per target in $4 x$ deep well 96 plates with $950 \mu \mathrm{l} 2 \mathrm{x}$ Blocking Buffer per well of. These wells will be used for the wash steps in the KingFisher protocol.

6. Centrifuge the pre-blocked Streptavidin beads at $800 \times \mathrm{g}$ for $1 \mathrm{~min}$. Place the tube on the magnetic separation rack and discard the blocking buffer.

7. Replace with fresh $2 x$ Blocking Buffer, resuspending in $100 \mu l$ per $20 \mu l$ of Streptavidin beads.

8. Pre-pan the phage: Mix $125 \mu$ l of phage-containing supernatant from the first panning round with $125 \mu \mathrm{l}$ of $2 x$ Blocking Buffer and add $25 \mu \mathrm{l}$ of the pre-blocked Streptavidin beads. For the negative selection, add the non-biotinylated homologous protein at a concentration of 10-100 $\mu \mathrm{M}$. Incubate for 1 hour at room temperature on the rotator.

9. Centrifuge at $800 \times \mathrm{g}$ for $1 \mathrm{~min}$ and place the tube on the magnetic separation rack. Transfer the supernatant containing the phage to a fresh tube and add another $25 \mu$ of the pre-blocked Streptavidin beads. Incubate for 1 hour at room temperature on the tube rotator.

10. Bind the target to the Streptavidin beads: Add $15 \mu \mathrm{l}$ (up to $750 \mathrm{ng}$ ) of biotinylated target to $200 \mu \mathrm{l}$ of 2x Blocking Buffer and $50 \mu \mathrm{l}$ of the pre-blocked Streptavidin beads. Incubate for 1 hour at room temperature on the tube rotator.

11. Remove buffer from the pre-blocked deep well 96 plate (step 4a) and the pre-blocked KingFisher (200 $\mu$ l) 96 plate (step 4b). Aliquot $100 \mu$ l per well of PBS into the pre-blocked KingFisher (200 $\mu$ l) 96 plate.

12. Centrifuge the tubes containing the biotinylated target at $800 \mathrm{xg}$ for $1 \mathrm{~min}$ and place on the magnetic separation rack.

13. Wash the beads containing the biotinylated target 3 times in $500 \mu \mathrm{l}$ of $2 x$ Blocking Buffer.

14. Centrifuge the tubes containing the pre-panned phage at $800 \times \mathrm{g}$ for $1 \mathrm{~min}$ and place on the magnetic separation rack for 1 min. 
15. Transfer the supernatant containing the pre-panned phage to the beads containing the biotinylated target and resuspend. Transfer to the pre-blocked deep well 96 plate (step 4a).

16. Setup the KingFisher Flex to run the protocol "Phage_Display_Competition" (see Table 1). The total run time is 1 hour $30 \mathrm{~min}$.

17. The protocol will release the beads into the $100 \mu$ PBS. Transfer the beads into Eppendorf ${ }^{\circledR}$ LoBind microcentrifuge tubes and add the following:

$$
\begin{array}{ll}
60 \mu \mathrm{l} & 10 x \text { Blocking Buffer } \\
60 \mu \mathrm{l} & 80 \% \text { Glycerol } \\
3 \mu \mathrm{l} & \text { Halt Protease Inhibitor Cocktail (100X) } \\
2.5 \mu \mathrm{g} & \text { Non-biotinylated protein for deselection } \\
& \text { PBS to a total volume of } 300 \mu \mathrm{l}
\end{array}
$$

16. Incubate at room temperature on the tube rotator up to 24 hours.

17. Pick a colony of ER2738 E.coli cells into $5 \mathrm{ml}$ of $2 \mathrm{TY}$ media with $12 \mu \mathrm{g} / \mathrm{ml}$ tetracycline and incubate overnight at $37^{\circ} \mathrm{C}, 230 \mathrm{rpm}$.

\section{DAY 3}

18. Pre-block plates for the KingFisher Flex magnetic particle processor for a minimum of 2 hours at $37^{\circ} \mathrm{C}:$

a. Pre-block one well per target in a deep well 96 plate with $1 \mathrm{ml}$ per well of $2 x$ Blocking Buffer. The competitively panned samples will be returned to this plate for washing and elution.

b. Pre-block one well per target two KingFisher $(200 \mu \mathrm{l}) 96$ plates with $300 \mu \mathrm{l}$ per well of $2 x$ Blocking Buffer. One plate will be used for eluting with glycine, the other for eluting with Triethylamine. 
19. Prepare one well per target in a $4 x$ deep well 96 plates with $950 \mu$ l per well of $2 x$ Blocking Buffer. This plate will be used for the wash steps in the KingFisher protocol.

20. Remove buffer from the pre-blocked elution plates (step 18b). Aliquot $100 \mu$ per well of $0.2 \mathrm{M}$ glycine, $\mathrm{pH} 2.2$, into one plate. Aliquot $100 \mu \mathrm{l}$ per well Triethylamine into the other plate. Remove buffer from the pre-blocked deep well 96 plate (step 18a).

21. An hour before required, set up a fresh culture of ER2738 cells ( $8 \mathrm{ml}$ per target) by diluting the overnight culture from step 17 to an OD600 of $\sim 0.2$ and incubating for approximately 1 hour at $37^{\circ} \mathrm{C}, 230 \mathrm{rpm}$ until $\mathrm{OD} 600$ reaches $\sim 0.6$.

22. After 24 hours of competitive binding, centrifuge the samples at $800 \mathrm{xg}$ for $30 \mathrm{sec}$, resuspend, and transfer to the pre-blocked deep well 96 plate.

23. Set up the KingFisher Flex to run the protocol "Phage_Display_Wash_Elute" (see Table 2).

24. The protocol is set up to incubate the beads in glycine for $10 \mathrm{~min}$ to elute the phage. As soon as this is finished, neutralise by adding $15 \mu \mathrm{l}$ of $1 \mathrm{M}$ Tris- $\mathrm{HCl}, \mathrm{pH}$ 9.1. Mix and add to the $8 \mathrm{ml}$ aliquots of ER2738 cells.

25. The beads are transferred into triethylamine for $6 \mathrm{~min}$ to elute any remaining phage. As soon as this is finished, neutralise by adding $50 \mu \mathrm{l}$ of $1 \mathrm{M}$ Tris- $\mathrm{HCl}, \mathrm{pH} 7.0$. Mix and add to the ER2738 cells.

26. Incubate the cells for 1 hour at $37^{\circ} \mathrm{C}$ (no shaking or shake at low speed, $90 \mathrm{rpm}$ maximum). Mix at least once during the incubation period.

27. Centrifuge the cells at $3,000 \times \mathrm{g}$ for $5 \mathrm{~min}$ to resuspend in a smaller volume and plate onto LB carb plates. Incubate overnight at $37^{\circ} \mathrm{C}$.

\section{DAY 4}

28. Prepare phage as described for the first panning round, Affimer Selection by Phage Display - First Panning Round steps 20-32. 
Table 1: KingFisher Flex Protocol "Phage_Display_Competition”

\begin{tabular}{|c|c|c|c|}
\hline Protocol Step & Plate & Volume $(\mu \mathrm{l})$ & Settings \\
\hline Tipcomb & 96 DW tip comb & & \\
\hline Pick-Up: Tipcomb & KingFisher 96 KF plate & & \\
\hline Collect Beads & $\begin{array}{l}\text { Plate: Binding } \\
\text { Microtiter DW } 96 \text { plate }\end{array}$ & & $\begin{array}{l}\text { Collect count } 1 \\
\text { Collect time (s) } 1\end{array}$ \\
\hline Binding & $\begin{array}{l}\text { Plate: Binding } \\
\text { Microtiter DW } 96 \text { plate }\end{array}$ & 300 & $\begin{array}{l}\text { Beginning of Step } \\
\text { Release beads [hh:mm:ss]: 00:00:00 } \\
\text { Mixing/Heating Parameters } \\
\text { Mix time [hh:mm:ss]: 00:00:10 } \\
\text { Speed: fast } \\
\text { Mix time [hh:mm:ss]: 01:00:00 } \\
\text { Speed: slow } \\
\text { End of step } \\
\text { Collect beads, count: } 5 \\
\text { Collect time (s): } 30\end{array}$ \\
\hline Wash 1 & $\begin{array}{l}\text { Plate: Wash } 1 \\
\text { Microtiter DW } 96 \text { plate }\end{array}$ & 950 & $\begin{array}{l}\text { Beginning of Step } \\
\text { Release beads [hh:mm:ss]: 00:00:00 } \\
\text { Mixing/Heating Parameters } \\
\text { Mix time [hh:mm:ss]: 00:01:00 } \\
\text { Speed: slow } \\
\text { End of step } \\
\text { Collect beads, count: } 5 \\
\text { Collect time (s): } 30\end{array}$ \\
\hline Wash 2 & $\begin{array}{l}\text { Plate: Wash } 2 \\
\text { Microtiter DW } 96 \text { plate }\end{array}$ & 950 & $\begin{array}{l}\text { Beginning of Step } \\
\text { Release beads [hh:mm:ss]: 00:00:00 } \\
\text { Mixing/Heating Parameters } \\
\text { Mix time [hh:mm:ss]: 00:01:00 } \\
\text { Speed: slow } \\
\text { End of step }\end{array}$ \\
\hline
\end{tabular}




\begin{tabular}{|c|c|c|c|}
\hline & & & $\begin{array}{l}\text { Collect beads, count: } 5 \\
\text { Collect time (s): } 30\end{array}$ \\
\hline Wash 3 & $\begin{array}{l}\text { Plate: Wash } 3 \\
\text { Microtiter DW } 96 \text { plate }\end{array}$ & 950 & $\begin{array}{l}\text { Beginning of Step } \\
\text { Release beads [hh:mm:ss]: 00:00:00 } \\
\text { Mixing/Heating Parameters } \\
\text { Mix time [hh:mm:ss]: 00:01:00 } \\
\text { Speed: slow } \\
\text { End of step } \\
\text { Collect beads, count: } 5 \\
\text { Collect time (s): } 30\end{array}$ \\
\hline Wash 4 & $\begin{array}{l}\text { Plate: Wash } 4 \\
\text { Microtiter DW } 96 \text { plate }\end{array}$ & 950 & $\begin{array}{l}\text { Beginning of Step } \\
\text { Release beads [hh:mm:ss]: 00:00:00 } \\
\text { Mixing/Heating Parameters } \\
\text { Mix time [hh:mm:ss]: 00:01:00 } \\
\text { Speed: slow } \\
\text { End of step } \\
\text { Collect beads, count: } 5 \\
\text { Collect time (s): } 30\end{array}$ \\
\hline Particle Release & $\begin{array}{l}\text { Plate: } \mathrm{pH} \text { elution } \\
\text { KingFisher } 96 \mathrm{KF} \text { plate }\end{array}$ & 100 & $\begin{array}{l}\text { Beginning of Step } \\
\text { Release beads [hh:mm:ss]: 00:00:10 } \\
\text { Speed: Fast }\end{array}$ \\
\hline Leave: Tipcomb & 96 DW tip comb & & \\
\hline
\end{tabular}

Table 2: KingFisher Flex Protocol “Phage_Display_Wash_Elute”

\begin{tabular}{|l|l|l|l|}
\hline Protocol Step & Plate & Volume ( $\mu$ l) & Settings \\
\hline Tipcomb & 96 DW tip comb & & \\
\hline Pick-Up: Tipcomb & KingFisher 96 KF plate & & \\
\hline Collect Beads & Plate: Binding & & $\begin{array}{l}\text { Collect count 1 } \\
\text { Collect time (s) 1 }\end{array}$ \\
& Microtiter DW 96 plate & & Beginning of Step \\
\hline Binding & Plate: Binding & 300 & Release beads [hh:mm:ss]:00:00:00 \\
& Microtiter DW 96 plate & & \\
\hline
\end{tabular}




\begin{tabular}{|c|c|c|c|}
\hline & & & $\begin{array}{l}\text { Mixing/Heating Parameters } \\
\text { Mix time [hh:mm:ss]: 00:00:10 } \\
\text { Speed: fast } \\
\text { End of step } \\
\text { Collect beads, count: } 5 \\
\text { Collect time (s): } 30\end{array}$ \\
\hline Wash 1 & $\begin{array}{l}\text { Plate: Wash } 1 \\
\text { Microtiter DW } 96 \text { plate }\end{array}$ & 950 & $\begin{array}{l}\text { Beginning of Step } \\
\text { Release beads [hh:mm:ss]: 00:00:00 } \\
\text { Mixing/Heating Parameters } \\
\text { Mix time [hh:mm:ss]: 00:01:00 } \\
\text { Speed: slow } \\
\text { End of step } \\
\text { Collect beads, count: } 5 \\
\text { Collect time (s): } 30\end{array}$ \\
\hline Wash 2 & $\begin{array}{l}\text { Plate: Wash } 2 \\
\text { Microtiter DW } 96 \text { plate }\end{array}$ & 950 & $\begin{array}{l}\text { Beginning of Step } \\
\text { Release beads [hh:mm:ss]: 00:00:00 } \\
\text { Mixing/Heating Parameters } \\
\text { Mix time [hh:mm:ss]: 00:01:00 } \\
\text { Speed: slow } \\
\text { End of step } \\
\text { Collect beads, count: } 5 \\
\text { Collect time (s): } 30\end{array}$ \\
\hline Wash 3 & $\begin{array}{l}\text { Plate: Wash } 3 \\
\text { Microtiter DW } 96 \text { plate }\end{array}$ & 950 & $\begin{array}{l}\text { Beginning of Step } \\
\text { Release beads [hh:mm:ss]: 00:00:00 } \\
\text { Mixing/Heating Parameters } \\
\text { Mix time [hh:mm:ss]: 00:01:00 } \\
\text { Speed: slow } \\
\text { End of step } \\
\text { Collect beads, count: } 5 \\
\text { Collect time (s): } 30\end{array}$ \\
\hline Wash 4 & $\begin{array}{l}\text { Plate: Wash } 4 \\
\text { Microtiter DW } 96 \text { plate }\end{array}$ & 950 & $\begin{array}{l}\text { Beginning of Step } \\
\text { Release beads [hh:mm:ss]: 00:00:00 } \\
\text { Mixing/Heating Parameters }\end{array}$ \\
\hline
\end{tabular}




\begin{tabular}{|c|c|c|c|}
\hline & & & $\begin{array}{l}\text { Mix time [hh:mm:ss]: 00:01:00 } \\
\text { Speed: slow } \\
\text { End of step } \\
\text { Collect beads, count: } 5 \\
\text { Collect time (s): } 30\end{array}$ \\
\hline pH Elution & $\begin{array}{l}\text { Plate: } \mathrm{pH} \text { elution } \\
\text { KingFisher } 96 \mathrm{KF} \text { plate }\end{array}$ & 100 & $\begin{array}{l}\text { Beginning of Step } \\
\text { Release beads [hh:mm:ss]: 00:00:00 } \\
\text { Mixing/Heating Parameters } \\
\text { Mix time [hh:mm:ss]: 00:07:30 } \\
\text { Speed: slow } \\
\text { Postmix[hh:mm:ss]: 00:00:05 } \\
\text { Speed: Bottom mix } \\
\text { End of step } \\
\text { Collect beads, count: } 5 \\
\text { Collect time (s): } 30\end{array}$ \\
\hline Triethylamine Elution & $\begin{array}{l}\text { Plate: Triethylamine } \\
\text { KingFisher } 96 \text { KF plate }\end{array}$ & 100 & $\begin{array}{l}\text { Beginning of Step } \\
\text { Release beads [hh:mm:ss]: 00:00:00 } \\
\text { Mixing/Heating Parameters } \\
\text { Mix time [hh:mm:ss]: 00:03:30 } \\
\text { Speed: slow } \\
\text { Postmix[hh:mm:ss]: 00:00:05 } \\
\text { Speed: Bottom mix } \\
\text { End of step } \\
\text { Collect beads, count: } 5 \\
\text { Collect time (s): } 30\end{array}$ \\
\hline Leave: Tipcomb & 96 DW tip comb & & \\
\hline
\end{tabular}

\section{Affimer Selection by Phage Display - Third Panning Round}

\section{DAY 1}


1. Aliquot $300 \mu \mathrm{l}$ per well of $2 x$ Blocking Buffer into NeutrAvidin-coated (HBC) 8-well strips and incubate overnight at $37^{\circ} \mathrm{C}$. Set up 6 wells in total for each target (4 wells for pre-panning the phage, one for panning against the target, and a negative control for panning against the deselected protein).

\section{DAY 2}

2. Wash $3 x$ with $300 \mu \mathrm{l}$ PBST per well on a microplate strip washer.

3. Aliquot $200 \mu \mathrm{l} 2 \times$ Blocking Buffer per well to the wells to be used for panning and $100 \mu \mathrm{l} 2 \mathrm{x}$ Blocking Buffer per well to the wells to be used for pre-panning. To the pre-panning wells, add 0.1-1.0 $\mu \mathrm{M}$ of the biotinylated homologous protein. Incubate for 1 hour at room temperature on a vibrating platform shaker.

4. Pre-pan the phage: Wash the first pre-pan well $3 x$ with $250 \mu$ l of PBST (manually, using a pipette). Add $20 \mu \mathrm{l}$ of $10 x$ Blocking Buffer and $200 \mu \mathrm{l}$ of phage-containing supernatant from the $2^{\text {nd }}$ panning round. Incubate for 1 hour at room temperature on the vibrating platform shaker

5. Wash the second pre-pan well $3 x$ with $250 \mu \mathrm{l}$ of PBST and transfer the contents of the first prepanning well to the second pre-panning well. Incubate for 1 hour and repeat for the third and fourth pre-panning wells.

6. Remove buffer from the wells to be used for panning against the target and negative control. Aliquot $100 \mu$ l per well of $2 x$ Blocking Buffer and add $10 \mu l(500 \mathrm{ng}$ ) of the biotinylated target or deselected protein. Incubate for 1 hour at room temperature on the vibrating platform shaker.

7. Wash the wells containing the target and the negative control $3 x$ in PBST.

8. Transfer $100 \mu l$ per well of phage from the pre-pan wells to the wells containing the target and the negative control. Incubate for $45 \mathrm{~min}$ at room temperature on the vibrating platform shaker.

10. Wash the panning wells $27 x$ with $300 \mu l$ per well of PBST on the microplate strip washer. 
11. Add the following: $80 \mu \mathrm{l}$ of $2 x$ Blocking Buffer; $20 \mu \mathrm{l}$ of $80 \%$ glycerol; $1 \mu \mathrm{l}$ Halt Protease Inhibitor Cocktail (100X); $2.5-5 \mu \mathrm{g}$ of the non-biotinylated protein for deselection.

12. Incubate for $24 \mathrm{~h}$ at room temperature on the vibrating platform shaker.

13. Pick a colony of ER2738 E.coli cells into $5 \mathrm{ml}$ of $2 \mathrm{TY}$ media with $12 \mu \mathrm{g} / \mathrm{ml}$ tetracycline and incubate overnight at $37^{\circ} \mathrm{C}, 230 \mathrm{rpm}$.

\section{DAY 3}

14. Setup a fresh culture of ER2738 cells ( $5 \mathrm{ml}$ per target and $5 \mathrm{ml}$ per negative control) by diluting the overnight culture to an OD600 of $\sim 0.2$ and incubating for approximately 1 hour at $37^{\circ} \mathrm{C}, 230 \mathrm{rpm}$ until OD600 reaches $\sim 0.6$.

15. Wash the panning wells $27 \mathrm{x}$ with $300 \mu \mathrm{l}$ per well of PBST on the microplate strip washer.

16. Elute the phage by adding $100 \mu \mathrm{l}$ of $0.2 \mathrm{M}$ glycine, $\mathrm{pH} 2.2$, and incubating for $10 \mathrm{~min}$ at room temperature.

17. Neutralise by adding $15 \mu \mathrm{l}$ of $1 \mathrm{M}$ Tris- $\mathrm{HCl}, \mathrm{pH}$ 9.1. Mix and add immediately to a $5 \mathrm{ml}$ aliquot of the ER2738 cells in a $50 \mathrm{ml}$ falcon tube.

18. Elute any remaining phage by adding $100 \mu \mathrm{l}$ of the diluted triethylamine and incubating for $6 \mathrm{~min}$ at room temperature.

19. Neutralise by adding $50 \mu \mathrm{l}$ of $1 \mathrm{M}$ Tris- $\mathrm{HCl}, \mathrm{pH}$ 7.0. Mix and add immediately to the ER2738 cells.

20. Incubate for 1 hour at $37^{\circ} \mathrm{C}$ (no shaking or shake at low speed,.90 rpm maximum). Mix at least once during the incubation.

21. Plate a range of volumes (for example $0.01,0.1,1,10$ and $100 \mu$ ) onto LB carb plates. Also centrifuge and plate remaining cells as described for the first panning round (Affimer Selection by Phage Display - First Panning Round, step 18). For the negative controls, just select one volume to plate (usually $10 \mu \mathrm{l}$ ). Incubate overnight at $37^{\circ} \mathrm{C}$. 


\section{Troubleshooting}

\section{Biotinylation Blocks the Active Site of the Target Protein}

The biotinylation reagent (EZ-Link ${ }^{\mathrm{TM}}$ NHS-Biotin) reacts with primary amines such as the amino termini of polypeptides or the amine of the side chain of lysine residues. Therefore, if there are lysine residues present in a functional region of a target protein, biotinylation of these residues could block access for binding in the selection process. Other biotinylation reagents that target different functional groups or residues are available. For example, the EZ-Link ${ }^{\mathrm{TM}}$ HPDP-Biotin reagent (Thermo Scientific, Cat. No. 21341) reacts with sulfhydryls, such as the side-chain of cysteine residues.

An alternative to chemical conjugation methods of biotinylation is enzymatic biotinylation. This is most often achieved by fusing the protein of interest with a Biotin Acceptor Peptide (BAP). The 15 amino acid peptide tag (GLNDIFEAQKIEWHE) serves as a highly specific recognition site for E. coli biotin ligase (BirA), which covalently attaches a single biotin molecule. Enzymatic biotinylation can be carried out in vitro but can also be achieved in vivo in the appropriate expression strains of $E$. coli.

\section{The Selection Procedure is Too Stringent}

Occasionally, our negative selection method has failed to select binders. This may happen when sequence homology between the two isoforms is especially high. This can result in the selection of weaker binders, which may be lost during the stringent deselection process. To decrease stringency, the $24 \mathrm{~h}$ incubation step during the second and third panning round can be removed and the phage eluted immediately after washing.

\section{Notes and Remarks}


A Nature Protocols paper described an in-depth protocol for a related technique, the selection of human antibody fragments by phage display (13). This method could of course be adapted for other phage display libraries, including the Affimer library; however this method does not describe a strategy to deselect against homologous proteins. Furthermore, our protocol uses lower amounts of target in each round of selection, which is advantageous for expensive or poorly expressed targets.

Our method was originally developed to select isoform-specific inhibitors of SUMO-dependent proteinprotein interactions (REF). Gilbreth et al. (14) described an alternative method, also utilising phage display for selection, and were successful in isolating isoform-specific monobody inhibitors of yeast SUMO (YSUMO) and the human SUMO-1 isoform (hSUMO-1). The authors expressed the targets (ySUMO, hSUMO-1 and hSUMO-2) as C-terminal fusions to a GST variant engineered to be devoid of cysteine residues except for a single cysteine for the purpose of biotinylation using the EZ-Link ${ }^{\mathrm{TM}}$ HPDPBiotin reagent. Monobody-displaying phage particles were pre-incubated with non-biotinylated GST from round 2 of selection to remove binders to GST. They did not employ this method of deselection to remove binders against the different isoforms of SUMO. They first identified monobody binders to ySUMO, then using crystal structure analysis of the binding mechanism, designed a SUMO-targeted monobody library that was independently screened against the different isoforms. Whilst this method isolated specific binders to hSUMO-1, it failed to isolate hSUMO-2-specific binders.

Our method has been successful in generating specific binders to numerous proteins and protein domains. The advantages of using the deselection method described here are that it requires only small amounts of target proteins, the process is relatively quick, and selection can be done from a large naïve randomised library. The stringency can also be adjusted by altering incubation times and wash steps. 


\section{References}

1. M. Baker, Reproducibility crisis: Blame it on the antibodies. Nature 521, 274 (2015); published online EpubMay 21 (10.1038/521274a).

2. A. Bradbury, A. Pluckthun, Reproducibility: Standardize antibodies used in research. Nature 518, 27 (2015); published online EpubFeb 5 (10.1038/518027a).

3. H. K. Binz, M. T. Stumpp, P. Forrer, P. Amstutz, A. Pluckthun, Designing repeat proteins: wellexpressed, soluble and stable proteins from combinatorial libraries of consensus ankyrin repeat proteins. J Mol Biol 332, 489 (2003); published online EpubSep 12 (

4. A. Koide, C. W. Bailey, X. Huang, S. Koide, The fibronectin type III domain as a scaffold for novel binding proteins. J Mol Biol 284, 1141 (1998); published online EpubDec 11 (10.1006/jmbi.1998.2238).

5. C. Tiede, A. A. Tang, S. E. Deacon, U. Mandal, J. E. Nettleship, R. L. Owen, S. E. George, D. J. Harrison, R. J. Owens, D. C. Tomlinson, M. J. McPherson, Adhiron: a stable and versatile peptide display scaffold for molecular recognition applications. Protein engineering, design \& selection : PEDS 27, 145 (2014); published online EpubMay (10.1093/protein/gzu007).

6. R. Woodman, J. T. Yeh, S. Laurenson, P. Ko Ferrigno, Design and validation of a neutral protein scaffold for the presentation of peptide aptamers. J Mol Biol 352, 1118 (2005); published online EpubOct 07 (10.1016/j.jmb.2005.08.001).

7. C. Tiede, R. Bedford, S. J. Heseltine, G. Smith, I. Wijetunga, R. Ross, D. AlQallaf, A. P. Roberts, A. Balls, A. Curd, R. E. Hughes, H. Martin, S. R. Needham, L. C. Zanetti-Domingues, Y. Sadigh, T. P. Peacock, A. A. Tang, N. Gibson, H. Kyle, G. W. Platt, N. Ingram, T. Taylor, L. P. Coletta, I. Manfield, M. Knowles, S. Bell, F. Esteves, A. Maqbool, R. K. Prasad, M. Drinkhill, R. S. Bon, V. Patel, S. A. Goodchild, M. Martin-Fernandez, R. J. Owens, J. E. Nettleship, M. E. Webb, M. Harrison, J. D. Lippiat, S. Ponnambalam, M. Peckham, A. Smith, P. K. Ferrigno, M. Johnson, M. J. McPherson, D. C. Tomlinson, Affimer proteins are versatile and renewable affinity reagents. Elife 27, 24903 (2017).

8. L. K. Stadler, T. Hoffmann, D. C. Tomlinson, Q. Song, T. Lee, M. Busby, Y. Nyathi, E. Gendra, C. Tiede, K. Flanagan, S. J. Cockell, A. Wipat, C. Harwood, S. D. Wagner, M. A. Knowles, J. J. Davis, N. Keegan, P. K. Ferrigno, Structure-function studies of an engineered scaffold protein derived from Stefin A. II: Development and applications of the SQT variant. Protein Eng Des Sel 24, 751 (2011).

9. J. Hanes, A. Pluckthun, In vitro selection and evolution of functional proteins by using ribosome display. Proc Natl Acad Sci U S A 94, 4937 (1997); published online EpubMay 13 (

10. R. Odegrip, D. Coomber, B. Eldridge, R. Hederer, P. A. Kuhlman, C. Ullman, K. FitzGerald, D. McGregor, CIS display: In vitro selection of peptides from libraries of protein-DNA complexes. Proc Natl Acad Sci U S A 101, 2806 (2004); published online EpubMar 02 (10.1073/pnas.0400219101).

11. D. S. Wilson, A. D. Keefe, J. W. Szostak, The use of mRNA display to select high-affinity proteinbinding peptides. Proc Natl Acad Sci U S A 98, 3750 (2001); published online EpubMar 27 (10.1073/pnas.061028198).

12. G. P. Smith, Filamentous fusion phage: novel expression vectors that display cloned antigens on the virion surface. Science 228, 1315 (1985); published online EpubJun 14 (

13. C. M. Lee, N. Iorno, F. Sierro, D. Christ, Selection of human antibody fragments by phage display. Nat Protoc 2, 3001 (2007). 
14. R. N. Gilbreth, K. Truong, I. Madu, A. Koide, J. B. Wojcik, N. S. Li, J. A. Piccirilli, Y. Chen, S. Koide, Isoform-specific monobody inhibitors of small ubiquitin-related modifiers engineered using structure-guided library design. Proc Natl Acad Sci U S A 108, 7751 (2011).

\section{Figure Legends}

Fig. 1. The Adhiron scaffold as determined by X-ray crystallography at $2.25 \AA$ (PDB: 4N6T). Highlighted in dark blue are the interaction loop residues (VVAG in loop 1 and PWE in loop 2) that were replaced with nine randomized amino acids (excluding cysteine residues) per loop in the library design (5).

Fig. 2. Affimer phage display selection conducted over 3 panning rounds. In each round of panning, the immobilised target (red dots) is incubated with a population of phage (green bars). After washing away any unbound phage, bound phage is eluted and propagated for subsequent rounds of selection. From Pan 2 onwards, the population of phage is first incubated with proteins homologous to the target protein to remove any phage that bind to these closely related homologs, before incubating with the intended target. 


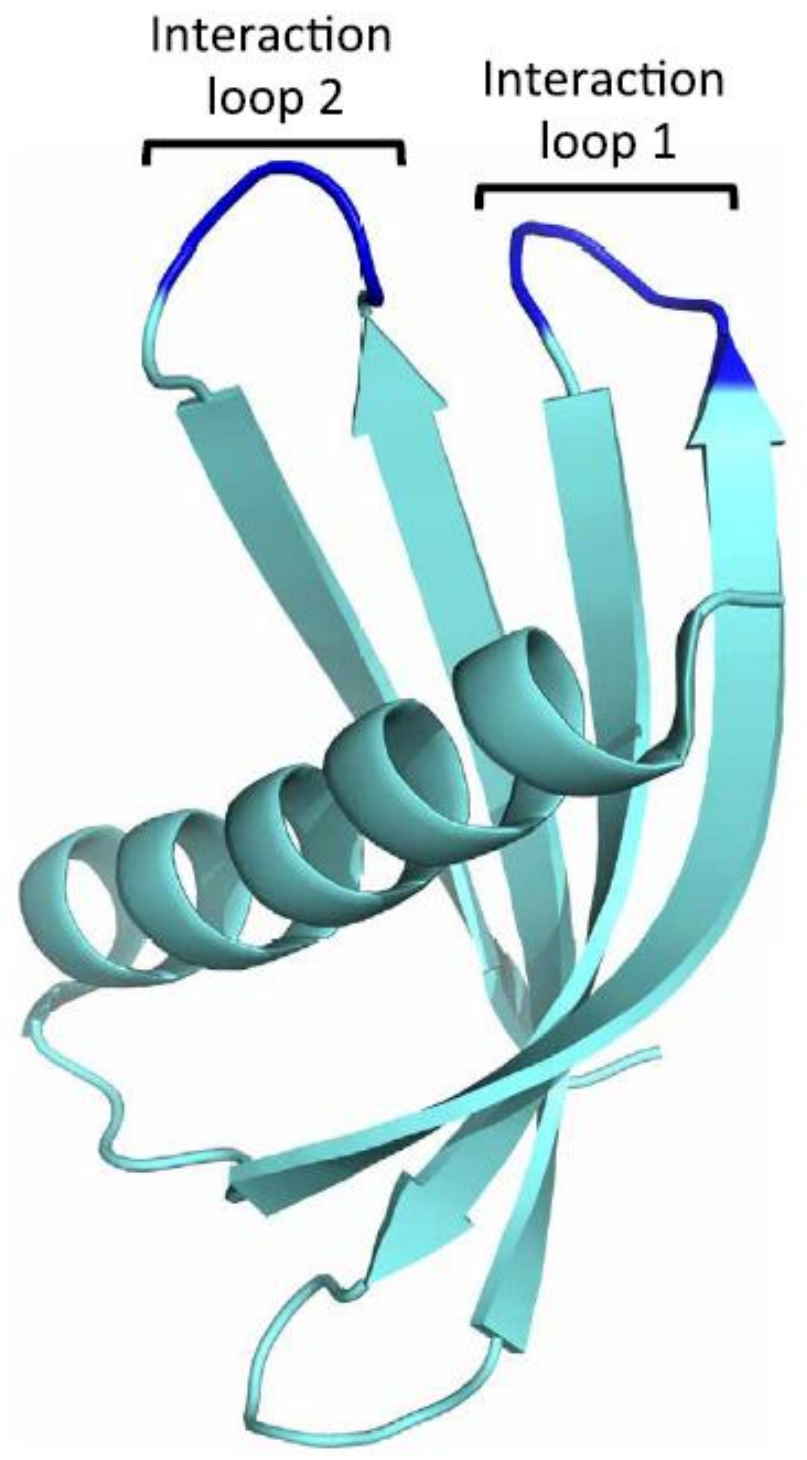


1. Immobilisation of biotin-target

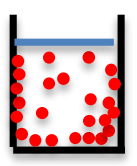

2. Incubation with phage

3. Phage elution
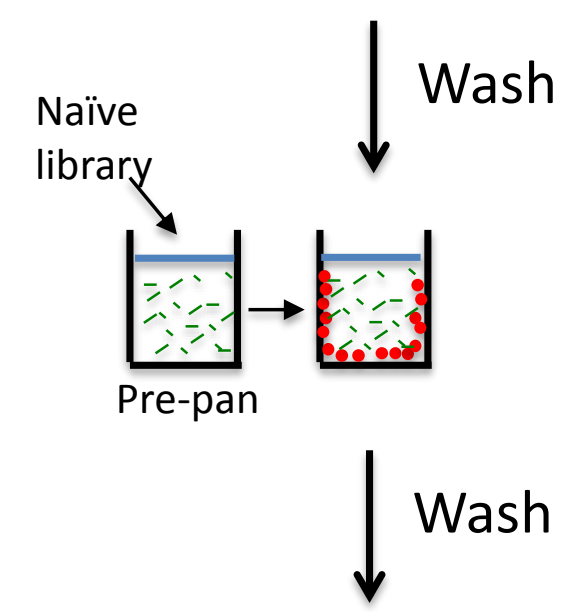

4. Infection of E. coli (ER2738), plating \& phage propagation

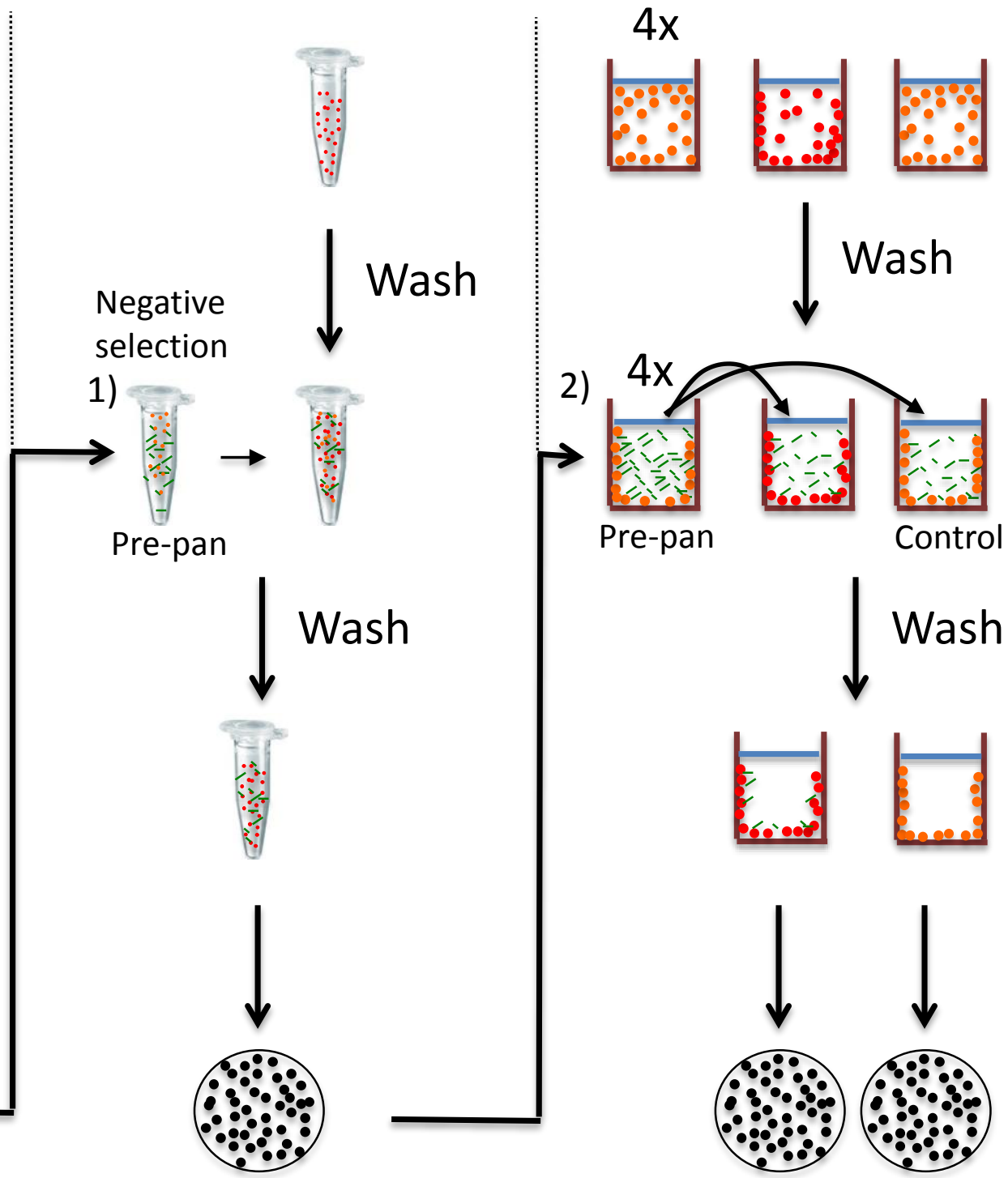

Control 